\title{
THE RISE OF INDIA IN THE NEW BALANCE OF POWER IN ASIA SINCE THE BEGINNING OF 21ST CENTURY: IMPACTS ON INDIA - VIETNAM RELATIONS \\ Tran Nam Tien
}

The University of Social Sciences and Humanities, Vietnam, and Vietnam National University - Ho Chi Minh City, Vietnam.

Email: trannamtienfir@hcmussh.edu.vn

Article History: Received on $5^{\text {th }}$ March 2021, Revised on $31^{\text {st }}$ March 2021, Published on $8^{\text {th }}$ April 2021

\begin{abstract}
Purpose of the study: The study focuses on the rise of India in the new balance of power in Asia since the beginning of the $21^{\text {st }}$ century. It had three major purposes: (a) to discover the new balance of power in Asia (b), to examine the possible predicting scenario about the role of India in Asia's order; (c) to understand critical influences of the Indian rise that affect on India-Vietnam relations.
\end{abstract}

Methodology: This study describes a qualitative study based upon a combination of three main methods such as historical method, analysis-synthesis method (documentary analysis), and case study method. The data were sourced from secondary data and content analysis in various publications of governments, foreign governments, or international bodies. Moreover, foreign policy journals, books, magazines, newspapers, and public records.

Main Findings: The study had some key research findings. The first main finding was that the rise of India would contribute to the common development of Asian countries and affirm the position of Asia on the world map. The second major finding was that India-Vietnam relationships supported India becoming a peaceful superpower dominating East Asia, especially Southeast Asia.

Applications of this study: The implications of the study can be supported by the observation of foreign policy substitutability. This study about the rise of India can be used to get the support of the policymaker or government to make the foreign policy adapting to the new era in Asia. Moreover, the study is also a valuable document for students majoring in International Relations, International History, and Politics.

Novelty/Originality of this study: There is no or has not been any study that discusses the rise of India in the new balance of power in Asia since the beginning of the $21^{\text {st }}$ century and its impacts on India-Vietnam relations.

Keywords: Balance of Power, Asia, India Vietnam Relations, $21^{\text {st }}$ Century, Content Analysis.

\section{INTRODUCTION}

In Asia, the unprecedented rise of China in economic power, as well as a military power in the first decade of the $21 \mathrm{st}$ century, has truly impressed the whole world. In the feudal era, China saw itself as the centre of the world, surpassing all other ethnic groups; and the Chinese Emperor was the "Son of Heaven" ruling the whole world. Therefore, China implemented a hierarchical system of foreign relations - "heavenly dynasty - vassals". With regional order styling Pax Sinica, China conducted its foreign relations with the Chinese Emperor's crowning king for the vassal states. China considered itself supreme compared to other vassal states bordering its country. Also, China, based on the experience gaining in the past, has always suggested that the biggest threat comes from the greater powers, which are trying to expand their influence in the buffer zone or setting up an order consisting of institutions and structures to serve only the interests of the major countries without the presence of China. Therefore, one of the most important objectives directing the thinking and actions of China in becoming the region's hegemony is to re-establish the international system bringing China interests and influence on others (Nguyen, 2012a). Initially, to "dominate" the whole of Asia, China is forced to beat the presence of the US in this region. The strategic objective of China in Asia is, by all means, undermining the US credibility as a guarantor for regional security. And the result that China wants is the US's recognition of China's hegemony in Asia in a geopolitical agreement to limit the US's role and presence in the region. Besides that, China also wants to dismiss the traditional American allies, especially the direct rival of China in Asia - Japan (Malik, 2014). Especially, one of China's strategic interests is influence by territorial sovereignty disputes with neighbouring countries in the "Emerging". China's aggressive behaviors, territorial claims, and geostrategic changes in the Chinese vision have increased tensions in the Indo-Pacific regions, which are the most important ocean for China's rise. In the second decade of the 21 st century, China took the strategic opportunities to gain influence in several "strategic spaces" when the United States made "power vacuum" in the Asia-Pacific and the Indian Ocean regions due to the [relative] weakness of the United States after the Global Financial Crisis (2007-2008). In the Asia-Pacific region, China has begun to have aggressive behaviors with its neighbors by diplomacy and military threats.

Besides that, unlike China, India's rise has been welcomed by the world. After the end of the Cold War (1991), India has introduced a series of reforms, notably an economic reform policy, which brought India to a market economy, liberalized and opened up, attached great importance to foreign economic relations. Entering the beginning of the twenty-first century, India began a strong resurgence with a diverse and fast-growing economy that is also a geopolitically important 
country, growing regional power. In the "Asian Century", the rise of India has been attracted by the attention of the world. After a decade of economic reform and transformation of the first decade of the 21 st century, India has the strong economic development and quickly established its power to affect its influence in the region. India's rise is judged to be "quality", therefore, observers forecast India will be a superpower in the future. Entering the second decade of the 21 st century, India is considered to play an important role in the region due to the decline of American influence in Asia, while China is emerging in Asia. India's growing economic and military might opens up the possibility that it could fill the void left by the US and become an Asian power actor.

\section{Research questions}

Question 1: How has India's rise in the early twenty-first century affected Asia's balance of power?

Question 2: How has the rise of India affected the India-Vietnam relationship?

\section{METHODOLOGY}

The study used a qualitative method, applying a combination of three main methods: historical method, analysis-synthesis method (documentary analysis), and case study method.

The data of this study were sought from two major sources. The first one was secondary data including published and unpublished data, such as various publications of governments, foreign governments, or international bodies. Moreover, foreign policy journals, books, magazines, newspapers and public records and statistics, historical documents, and other sources of published information were used. The second data source was content-analysis consisting of analyzing the contents of documentary materials like books, magazines, newspapers, and the contents of all other verbal materials which can be either spoken or printed. These two main methods were used due to the descriptive nature of the study.

\section{RESULTS AND DISCUSSION}

\section{The new balance of power in Asia since the beginning of 21st Century}

Theoretically, the power in the international system is relative and always changing, especially at a regional level. For a long period, Europe has been considered as the world's centre of development. However, since the beginning of the $21^{s t}$ century, many people have predicted obviously that this century would be the century of Asia, especially the Asia Pacific region (Mahbubani, 2008). This perception comes from the impressive development of East Asian countries, in which, China is seen as a new power centre in Asia with a strong economical rise, commensurate demands on military power, and political voice not only in the region but also in the world. In that context, there are clear signs in Asia showing that the old system with the dominance of the United States can no longer be extended due to the emerging challenges of China, along with their lative weakness of both the US and Japan. As can be seen, the rise of China has challenged the hegemonic position in Asia - Pacific, conflicts directly with the "national interest" of the US in this area. The rise of China "has created the fast, reliable and largest shift in the balance of power in the contemporary East Asia, limited the influence of many major countries in the region, primarily the US and Japan” (Nguyen, 2012b).

In the past three decades, China has demonstrated its incredible capabilities in building many strategies, plans and successfully mobilized national resources to implement the action strategy with specific targets in areas such as economy, diplomacy, and military. Thanks to the continuing growth at a high level in the economy for more than three decades, at the end of 2010, China officially surpassed Japan to become the world's second economy with the gross domestic product (GDP)of5,880 billion USD, equivalent to about 40\% of US's GDP (14660 billion USD). However, in terms of purchasing power (PPP), the GDP of China was equal to around $68.7 \%$ of that of the US. If China can maintain its momentum, some factors such as the GDP, military, research, and development expenses of this country can compete with similar indexes of the US, not in quality but quantity. Moreover, it is likely to overtake the US GDP in the next 15-20 years. Nevertheless, in terms of purchasing power, China's GDP is likely to surpass the US's within the next decade to become the largest economy in the world in terms of scale (Nguyen, 2012b). From the perspective of power, China is now emerging as an arrival on par with the US. It was even considered to be stronger than the Soviet Union during the Cold War.

In essence, no rising powers accept their recent status quo. They always have the ambition to expand. Since the financial crisisin2008, China has shifted its policy from "keeping low-profile" to "striving for achievements" to rise to the top and display power to orientate the choice so for the parties towards its own advantages. In which, China has considered Asia as the "buffer" for the rise of itself; and of course, China will never accept to share its power with any other country in the region. Like the other major powers, especially the US, China has a long history of expansionism. As can be seen, the "expansion" of China had different characteristics from European colonialism with a "heavenly dynasty-vassals" tributary system. The purpose of China's tributary system is to impose its dominant power on the surrounding countries, especially on the policies of those countries (Dupont, 2012).

However, apart from the US - the external factor of the region, the rise of China also faces challenges coming from Asia. Under the leadership of Mr. Shinzo Abe, Japan is becoming a "normal country" with the lifting of collective self-defense and weapons transfer barriers. Witnessing the reinforcement in military strength and assertiveness of China, Prime Minister Shinzo Abe has pledged to strengthen the defense of Japan, tighten alliance with the United States, and promote 
security cooperation with the Asian countries which have the same concerns about China. However, the biggest issue of Japan is the significant dependence on the US security (Mochizuki \& Porter, 2013). India has also rebalanced in terms of economics and strategy towards the Asia-Pacific region for nearly two decades to implement the "Look East Policy". With the victory of the BJP in the election in May 2014 under the leadership of Mr. Narendra Modi, India is predicted to come back powerfully with the basic adjustment in foreign policy, in which the shift from the "Look East Policy" to "Act East Policy" showing great determination in changing the balance of power in Asia (Rajendram, 2014). As expected, a developed India is predicted to become the protector for the balance of power of Asia in the south and avert the attempts to establish the suzerain position of China. Meanwhile, the middle powers such as South Korea, Indonesia, the Philippines, and Australia are actively acting for the target of balance and gaining advantages upon the basis of taking advantage of the conflicts between the powers in the region. Facing the strong and ambitious "rise" of China, these countries increasingly seek ways to "consolidate" together to form a strength. With initiatives promoting peace and cooperation in the region, these middle powers have also created essential voices in the international issues of the region. ASEAN, as a regional organization, also have a certain influence on the political chessboard in East Asia in particular and Asia in general. It is indispensable to consider Russia, a country that seems not much related to Asia after the Cold War. However, in the process of returning to the global political stage, Russia needs to pay attention to Asia. It could be said that all of these have created an extremely tricky and complicated geopolitical environment in Asia.

Overall, the current power structure of East Asia is partly similar to the situation of Europe in the early twentieth century. It was the time the leading nations in Europe such as Britain, France, Germany, Italy competed against each other to reach out to the world to seek markets, resources; fight for power and influence, pinch and scramble across countries and regions over the world, thereby, forming a natural partnership is the feature of prevention strategies. No doubt, the rise of China will become one of the most outstanding plays of the XXI century. China's extraordinary economic development and flexible foreign policy have created changes for East Asia, and in decades in the future, the world would witness the stronger growth of China's power and influence (Ikenberry, 2008). Currently, the power competition in Asia is mainly between the US and China, but in the ocean and on land, it is the competition among China, Japan, and India. On that basis, Japan and India have the same concerns about their position in Asia which China is at the center position. That will enhance future Japan - India relations with the implicit backing of the US. This fact likely increases the strategic competition, even conflicts among China and Japan and India, and the US further. Thus, at the beginning of the $21^{\text {st }}$ century, there has been several nations raising with full of competitiveness while some nations weakening and becoming vulnerable in Asia. The rising powers are forming a new strategic balance since partnerships and alliances among nations have changed (Malik, 2014). In this prospect, there will no longer be the "presence" of the US and China will emerge as the dominant factor in the movement of international relations in the region (Tang, 2011). Besides, Dat, P.M., Mau, N.D., Loan, B.T.T., \& Huy, D.T.N. (2020) also mentioned that China's corporate governance standards can be used as references for other developing countries.

In general, the strong movements in power interaction and interdependence among the actors of international relations in the region have increasingly affirmed that Asia is becoming the center of the movement of contemporary world politics. Besides is the shift of global power to the East together with the challenge by the global power of the US coming from a small number of new factors, typically China and further India. Although there are still complicated progresses from traditional to non-traditional security in the region and the world, the trend of peace and cooperation plays a key role that contributes to the behaviors based on the rules and the peaceful, cooperating values to be highly appreciated. In that context, India with awareness as a big nation and responsibility in the region has massively invested for the process of "rising" powerfully, towards the establishment of the power position in the region and a world-leading power in the future. The "rising" of India is understood as the "rising" of an actor in terms of economy and politics powerfully controlling the movement of international relations in the region and around the world.

\section{The "rising" of India in the new balance of power in Asia}

There are some moments in international politics when the change of power is a particularly critical feature, which will change the whole world. After the end of the Cold War, the sudden collapse of the Soviet Union (1991) has changed the balance in the global influence. Some analysts have predicted a "post-American world", or used the term "infinity" (Haass, 2008) to describe a world in which America's unipolar moment has passed and there is no existing power replacing that position. Besides that, the rising of some countries or certain regions, especially China and India, becomes the new focus of the world system. At the beginning of the XXI century, the nature of the US role in the global order seems to have been changed (Hart\& Jones, 2010).

The powerful movement in the power interaction and the interdependence among the international relation actors in this region has gradually confirmed that Asia is really becoming the centre of the political movements of contemporary world politics. If the nineteenth century can be seen as "the British century" and the twentieth century can be considered as "the US century", the twenty-first century should also be seen as "the Asian century". Along with that is the shift of global power to the East and the challenge of the American's global power coming from a small number of new elements, such as China and India. Although there are still complicated progresses from traditional to non-traditional security in the region and the world, the trend of peace and cooperation plays a decisive role in contributing to the appreciation of the behaviors based on the rules and the values of the peace and cooperation. Also in this context, the "rising" of India is 
considered as the "rising" of a powerful actor in terms of economy and politics, which has the ability to control the movement of the international relations in the region and around the world.

Basically, a "rising" country can be recognized through the rapid growth of economic and political potential; thereby narrowing the gap with the more developed countries, catching up with the lead excel in a few (or many) indicators, at least on some aspects such as economy, politics, military ..., in comparison with some of the major powers in the region and on the world. In particular, an exceeding rise in the economic scale and the influence of national politics have an impact [mainly in the field of security] on many other countries, leading to the attention and tackling strategy of many countries on the regional and global scale. According to Andrew Hurrell, besides the increase in economic strength, all of these countries are at a relatively high level, at least in the military potential and political power resources, with the internal coherence being set at a reasonable level and some ability to contribute to the formation of a new international order. Besides that, every country desires to have a more influential role in global affairs (Nguyen, 2012a). From the above perspectives, the "rising" of India is in fact the adjustment in economic development and external policy, which is compatible with the inevitable movement of a major power in the new century.

As one of the first four civilizations of mankind, Indian cultural values and civilization have soon become a valuable part of Asia through an early exchange process. After the end of the Cold War (1991), India made plenty of important adjustments in economic and external affairs policy. In which, the objectives of India's external policy prominently show the ideas of associating India's development with regional development and integrating with the development trend of the times without changing the values of national identity. These objectives are: Protecting national independence, sovereignty, and security; Creating an environment of peace and stability for economic development; Strengthening and expanding relationships with major countries, with the economic centres of the world to take advantage of investment and high technology; Speeding up the process of regional and global integration; Enhancing the role and position of India in the region and on the world, making India a great nation in Asia and on the world in the first decades of the twenty-first century, having a deserved position in the new world order.

The highlight of the Indian strategic vision is to affirm the role of the regional and global power, which is the coherence between India and Asia created by promoting the Indian economy integrating into the Asia-Pacific region. In terms of geographical location, India is located right at the end of the Asia-Europe median line of silk in particular, and between the East and the West in general. Especially, the section promontory of the Indian Ocean looks like a launchpad towards the ocean and the two directions East-West. At the same time, it can also be a protective shield in need for the southern region and Central Asia (Nguyen, 2014). Being thoroughly aware of this, India, on the one hand, focuses on "inward" activities to determine its influence on the traditional territories of South Asia; on the other hand, India also conducts "outward" policy on the basis of regulating the domestic and foreign interests for the country. If the security and prosperity in the country are the platforms to extend its influence regionally and globally, the ability to create transregional influence plays a decisive role in the consolidation of India's national interest. The sub-regional agreements which have been signed recently will help India implement the "East Action" policy through the strengthening of trading relations, connecting as well as building strategic relations with major powerful countries in Asia (Deo, 2015).

In the "rising" process, India is always aware of the scale of a "responsible" major towards the development of the region with other countries in it, and tries to show "responsibilities" on a global scale. The influence of India is expressed through its effort in associating with Japan, strengthening its relations with middle powers such as South Korea, Australia, Indonesia, and the vision of engagement with the US and European Union (EU) on economic interests. In a larger perspective, India is also actively promoting its role in the major economies through BRICs, World Trade Organization (WTO) ... Besides that, India is also trying to seek for support from the world powers to help the country become a Permanent Member of the Security Council of the United Nations in the near future (Patnaik, 2004). One outstanding feature is that the "rising" of India is placed in the context of long-race competition with China; the impending ones are the economic sectors and political influence in traditional regions. India has frankly admitted the fact combined with a future vision that "China is winning the sprint, and we are going to win the marathon." (Meredith, 2008). This shows that India will focus on the result rather than the process; thereby showing the serious and focused investment. In addition, A limited South Asian corporate governance standards were also mentioned being used as references for other markets (Huy, D.T.N., 2015).

It can be said that the "rising" of India is clearly expressed through economic growth. If the total gross domestic product (GDP) of India in 1990 was 320.3 billion USD, the one in 2014 reached 2,066 billion USD. Thus, within less than a quarter of a century, the GDP of India has grown up nearly 6.5 times. For the past 15 years, India has always been the country with the second-fastest pace of development at an average of $6 \%$ per year, only behind China. In 2015, its growth rate increased up to $7.5 \%$ (Zakaria, 2006). Some recent reports by the IMF and the World Bank have pointed out that in India, industry only accounts for $24 \%$ while service makes up $58 \%$. This shows that India is investing massively in resources through education reform programs to train the engineers and the scientists - who are really important to the success in the world of globalization, creating the basis for the process of entering the knowledge economy. As reported by Forbes in 2016, India is also integrating into the global economy closer than China. When comparing these two countries, this is not surprising that although China accounts for $17 \%$ of global GDP while India accounts for only $7 \%$, Indian exports reach a GDP proportion much larger than that of China (MacKie, 2016). A study carried out in 2003 by 
Goldman Sachs has predicted that within the near 50 years, India would be the fastest-growing country among the major economies in the world. According to Goldman Sachs' calculation, within ten years, the Indian economy will become stronger than Italy's and in 15 years it would replace the position of the UK economy. By 2040, India will be proud of being the third-largest economy in the world (Zakaria, 2006).

As can be seen, all outstanding economic achievements of India for the past few years are the result of the liberalized economic reform process, focused on expanding trade relations and investing in major countries at the beginning of 1990. Besides, India also focuses on strengthening key industries of interest combined with a comprehensive reform of agriculture in order to build a strong industry - agriculture complexes. The BJP government decided to dismantle trade barriers and carry out the necessary reforms to attract investment along with the campaign "Made in India", which makes them believe that once the government continues to invest more in infrastructure and train a large number of young people (Ragavan, 2015), then India will dominate the global economy, and there will be a likelihood to surpass China in the coming years. As it can be said, the economic reform policies of India to affirm the resilience of the economy have been increasingly becoming effective.

India is interested not only in the economic development within the country but also in pushing cooperation and development with some countries in its traditional areas of South Asia. India shows its responsibility as a national leader and as the fulcrum of South Asia's development (Pham, 2013). Actually, India is the strongest developing country in an economy in South Asia; thus, India has become the economic pillar of the region. The strengthening in economic cooperation between India and the South Asian countries has won much important consensus. With this perception, India is making self-innovation efforts to make the friendly diplomacy and cooperation with South Asian countries (Banskota, 2012). Based on the positive contribution of India to the development of the region, South Asia has gradually won the world's sympathy and been more open to change perceptions about an "always conflicting" South Asia (Hagerty, 2005). The strong growth of the Indian economy has also gained the "attraction" of India in the perception of East Asian and ASEAN nations. India's efforts in economic integration with the East Asian countries have been welcomed in this region. India participated in the East Asia Summit in 2005, which was a success in the process of integration into this dynamically developing region (Kesavapany, Mani \& Ramasamy, 2008).

Information Technology is also identified as a key economic sector in India, contributing to solving the problems of social security, which attracts a large amount of foreign investment and boosts the economy to thrive and improve the position of this South Asian country. It can be said that strong scientific and technological development has drastically put impacts on the speed of India's economic development, restructuring the economy of the country from traditional agriculture to industry and service (Singh, 2016). One of the biggest advantages of India for the development of information technology is the rapid adaptation of this country to a market economy and the process of globalization nowadays. At the same time, India also attracts numerous professional and talented engineers in the business, selected information technology; thereby contributing a workforce of experienced digital and intelligent experts, which leads to the prosperity of the economy and of the country. With the major investment in the field of information technology, India has grown from a poor and outdated country with an underdeveloped and stagnant economy to an "information technology powerhouse" in the world after only a short time (Majumdar, 2012). Currently, India has gained the world's admiration for the breakthrough in the information technology field and has become the world's centre of information technology services. Along with those key fields, the high-qualified human resources (particularly in the technology sector) being trained both domestically and abroad is the strength of India. Many big companies in the world have used a number of skillful workers from India. The takeoff of Indian technology is the phenomenon of the world and thus increases the competitiveness with the US (Tran, 2013).

With the rapid development of the economy and technology, India has also increased its political influence domestically and internationally as a "begin power" (Sachdeva, 2016). It can be clearly seen that the "rise" of India has gained the support of the international community with the ideas of peace and sustainable development that this country has brought out, as well as their positive contribution to a peaceful regional cooperation. India's foreign policy, which emphasizes on economy and a tight combination between nationalism and pragmatism in maintaining strategic relations with the US, tends to expand foreign relations to the Far East and search for priority interests in its relations with East Asian countries. Besides, India also actively maintains its role as a leader of the developing countries (Pham, 2013). The "Look East" policy was set out at the beginning of the last decade of the twentieth century, which is now the "Act East" policy of India. It is concretized for India's strong interaction with East Asia and especially focuses on the ASEAN countries. Accordingly, the fields which are cooperated between India and the major partners in the region such as Japan, Korea, Australia, the US, and ASEAN countries, are also strengthened and expanded in terms of range from economic sectors to maritime security, counter-terrorism, transnational crime, disaster relief, humanitarian aid, ... In particular, the relationship between India and the US has been more positive since the terrorist attacks dated on September 11, 2001. It is proved by India's active support of the US in the fight against terrorism. The US support for India's role in the region also stems from its "pivot to Asia" policy in the US and its concerns about the rise of China (Gupta, 2007; Bertsch \& Gahlaut \& Srivastava, 1999).

Besides the investment in the development of a superior economy, a country cannot become a superpower without investing in military power both domestically and externally. After the end of the Cold War, India also had a fundamental 
reform of its military strength in parallel with economic and foreign policy. However, in comparison with the process of military modernization of China, India is only at the beginning of the modernization process. India must recognize that China now has a powerful and advanced military force, which outnumbers India's (Tabata et al.,2015). However, in terms of technology, India is on the way to overtaking China. India has invested in training a number of scientists, designers, the world's best engineers. Moreover, thanks to its openness and willingness to cooperate with other countries, the changes are beginning to be shown. It can be said that India was on the way to catch up with the military capabilities of China based on the scientific and technological achievements which are used in the generation of the new aircraft and warships being deployed (Ladwig, 2010). Currently, India is attempting to modernize its military to enhance the ability to guarantee security belt from the Indian Ocean to the Pacific Ocean as a great ocean power. With a coastline of 7,516.6 kilometers (Scott, 2013), Indian Navy Commander in Chief Arun Prakash emphasized that India possesses both opportunities and challenges "in the geographical advantage" through appropriate strategies (Prakash, 2011). Recognizing this, India has invested massively in naval development. Indian Navy is currently one of the largest naval forces in the region. India is increasing its military capabilities, especially the navy is to ensure its security for energy not be hampered by any country. Included in the strategy to strengthen the control of the Indian Ocean, India has rapidly developed the defence strategy on the sea by combining the capabilities and military forces to directly protect national security on land, in the sky, and the ocean.

Besides, to make a difference, India focused on multilateral development in the military sector, aiming to develop a strong military not only in the modern defense sector but also in terms of nuclear, biological, and chemical weapons (Kapur, 1997). The evaluation of the "rise" of India in the new context still cannot eliminate the possibility of serious consideration about Indian's true position in the twenty-first century. Regarding the position of India, there is still controversy about classifying India as a regional great power or a global great power (Babbage \& Gordon, 1992). Currently, there are statements suggest that India is a "Tier II power", which is still incommensurate with the US and China. In particular, the strategic focus of India's relations is based on trust, mutual respect, and mutual benefits. Having the vision of the balance of power in the region with the support of a strong political will of regional security is what India is pursuing (Bhatia, 2013). In essence, the recognition of the power of India will contribute to the peace and development of the region and the world. In recognition of India's leadership, the "rise" of this country has not been mentioned, but it has been the vision, the mission, and the development of India in the new context instead. Avoiding mentioning the "rise" in the mainstream view of India is not evade the country's role with global responsibility. In fact, Indian leaders remain focused on economic policy and national reforms to strengthen the political position rather than a single policy focusing on expanding influences outwards. Besides, India is cautious in taking on global commitments because if India expresses its ambitions too early like the Chinese with "rising peacefully" statements, it can generate responses from the international community like the case of China before. It is also seen as a necessary caution to India in the development process towards establishing a world power role today.

\section{Impacts on the relations of India - Vietnam}

After the Cold War ended (1991), India has had a major adjustment in the field of foreign policy, in which the most notable was the introduction of the Look East Policy. In the Look East Policy deployment, Vietnam has a very important position, especially in terms of security and strategy. In terms of history, Vietnam and India have a long-lasting history of relations. However, diplomatic relations between the two countries were officially established in 1972. In the early years of the twenty-first century, the relations between Vietnam and India have begun to go into depth and become a model for collaboration of peace and friendship between the two countries, the two races in Asia. Until July 2007, India and Vietnam officially established a strategic partnership, lifting the cooperation between the two countries to a new level. Thus, Vietnam became the first country in Southeast Asia and second in Asia - Pacific (after Japan) to officially establish strategic relations with India. Once elected, Prime Minister Shri Narendra Modi (May 2014) also proactively adjusted Indian foreign policy, which upgraded the "Look East" Policy to the "Act East" Policy. Under Modi's administration, India no longer conceals its desire to play an active political and security role in the Asia-Pacific region as it gradually expands its economic and strategic influence through the "Act East" Policy and strengthening multilateral diplomacy. In this context, the actor that plays a key role in helping India maintain a long-term presence in the region is Vietnam. On the basis, India - Vietnam Strategic partnership has been built as a new momentum of development, not only within the scope of bilateral relations but also expanded the relationship to cooperate on a range of international and regional (Do, 2012).

In the "Look East" and now the "Act East" Policy, Vietnam is considered to be an "essential pillar" and an "important bridge" in the expansion of relations between India and the countries in the region [South East Asia] (Elliott, 2012). In Indian strategic perception, Vietnam has a very important role in promoting the interests of politics, economy, and security of India in Southeast Asia, and even the success of the "Act East" policy in India's Modi era. It can be said that India has recognized the strategic location of Vietnam's important role in the center of the Indochina peninsula and the South China Sea for a long time. The increasingly strained relations between Vietnam and China and the geostrategic position of the country in Indochina and the South China Sea have made Vietnam become a natural partner for India to balance the relations with China in the region. On that basis, India has maintained good relations with Vietnam, and active support for Vietnam with the aim of the strategy is against ambitions to dominate the region's other great powers (Brewster, 2012). 
With the development of the current facility, Vietnam is a potential regional power in Southeast Asia with the great political stability, positive economic growth. With this rather high growth rate, Vietnam has become one of the fastestgrowing markets in Southeast Asia in 2016. Under the strategic prism of India, Vietnam's economy has begun its liberalization with very attractive incentives for sources of foreign direct investment (FDI) in India, and the fact that India can facilitate energy security in offshore Vietnam and the political support of Vietnam actively is factors binding the bilateral relations. In the region, the voice of Vietnam is increasingly weighing. Since having been admitted to ASEAN (1995) until now, Vietnam has shown a positive attitude and sincerity which have many important contributions to the strengthening of cohesion and sharing among members in the organization as well as between organizations and other countries outside the region. It can be said that Vietnam is increasingly proving to be a bridge of peace and confidence to countries outside the region establishing deepened relations with ASEAN. This fact shows that Vietnam has been "proactive, positive and responsible along with other countries to build a strong ASEAN Community, strengthening relations with partners, continue to hold an important role in the framework of cooperation in the Asia-Pacific" (Dang Cong san Viet Nam, 2011). Besides, a sustainable partnership of Vietnam - India has a very important role in the realization of the strategic interests of India in the field of maritime and pushes Vietnam's efforts to strengthen the presence of the international reliable partners in the region (Mishra, 2014). It is in this context that the contribution of Vietnam in ASEAN has been confirmed, the Indian has chosen Vietnam as a dynamic factor and an effective way to reach out to ASEAN.

In the new stage of development, Vietnam and India have identified "five pillars" key in strategic partnership - covering many important areas of bilateral relations, including politics, economy, energy, security and defence and other sectors (culture, tourism ...) (Thayer, 2014). It can be seen that positive trends in India - Vietnam relations stem from the common aspirations of India and Vietnam to create a Southeast Asian regional peace and balance (Bhatia, 2014). Besides, a sustainable partnership of Vietnam - India plays a major role in the realization of the strategic interests of India in the field of maritime and pushes Vietnam's efforts to strengthen the presence of the international reliable partners in the region (Mishra, 2014).

On the Vietnamese side, the "rise" of India, firstly as an economic powerhouse, is more likely to accelerate the process of economic liberalization, especially in attracting bilateral and multilateral FTAs to strengthen regional cooperation. Once a regional economic link is strengthened, the political-economic stability in the region will attract the participation of many actors of international relations. In particular, the economies of small and medium scale in the region will also see this as a good opportunity to gradually adjust the economic development strategy to gradually increase competitive advantage and adapt to the "rise" of India. In this context, strengthening cooperation with India will bring many advantages and resources needed for the national development of the developing countries like Vietnam today.

From the above perceptions, political - diplomacy relations between India and Vietnam are promoting a strong network, provide the basis for the development of other vital sectors. Most notable is the visit to India of General Secretary Nguyen Phu Trong in 2013. During this visit, the two countries issued a joint statement with 32 points. In this joint statement, General Secretary Nguyen Phu Trong and Prime Minister Manmohan Singh emphasized the commitment to strategic economic partnership, cooperation, and cultural exchanges as well as the cooperation of the People's Forum regionally and internationally. With defence - security, the two leaders agreed that defence cooperation has become an important pillar of the strategic partnership between the two countries. With the economic partnership, the two leaders agreed to upgrade relations to become one of the main contents of the strategic partnership between the two countries.

On the Indian side, the visit of Indian President Pranab Mukherjee to Vietnam in September 2014 was an important turning point in the history of diplomatic relations between the two countries. Speaking at the talks with the President of Vietnam, President Pranab Mukherjee confirmed that Vietnam is a very important pillar of India's "Look East", a strategic partner of India in ASEAN as well as in the wider region. President Truong Tan Sang also affirmed that Vietnam always attaches importance to constantly develop the strategic partnership between Vietnam - India. The two sides agreed to strengthen and deepen the strategic partnership of cooperation with a focus on political, defence, security, economic, scientific-technical, and other key issues. After that, in October 2014, Prime Minister Nguyen Tan Dung paid an official visit to India. At the meeting on October 28, 2014, Prime Minister Nguyen Tan Dung and Prime Minister Modi have reaffirmed commitments to the comprehensive development of "strategic partnership" between the two countries. While Prime Minister Modi emphasized that Vietnam is an important pillar in India's "Look East Policy", Prime Minister Nguyen Tan Dung also welcomed India as a greater role in the region and the world; Vietnam confirms its support for India's Look East policy and connectivity in all aspects of India in the region.

India-Vietnam relations turn a new turning point in India's Prime Minister Narendra Modi's visit to Vietnam in September 2016. During this visit, bilateral relations were further elevated to a "Comprehensive Strategic Partnership". This is evidence reflecting the deep, reliable, and effective development of Vietnam - India relations over time. Thereby, "Comprehensive Strategic Partnership" relations have gradually promoted economic, defence, and security relations of the two countries in a depth, substance manner. Besides that, fifteen years after the official visit to Vietnam of the former Indian Prime Minister A. B. Vajpayee, Prime Minister Narendra Modi made an official visit to Vietnam in 2016, showing that New Delhi has no longer hesitated in expanding its presence on China's periphery. The Modi's administration has made no secret of its desire to play a more assertive role in the Indo-Pacific region. Moreover, Modi stated that India can 
anchor peace, prosperity, and stability from Asia to Africa and from the Indian Ocean to the Pacific. Therefore, the shift to reach Vietnam with greater ambitions should not be surprising. In March 2018, Vietnam's President Tran Dai Quang made a three-day State visit to India to affirm the importance of the relationship and mark a significant milestone in the bilateral relations in the rapidly changing world.

In the context of cooperation in India - Vietnam relations, economics, and trade has always been one of the highlights of comprehensive cooperation of Vietnam - India. In October 2009, the Government of India has recognized Vietnam as a country with a market economy in full and the two sides signed the Agreement on Trade in Goods of the Framework Agreement on Comprehensive Economic Cooperation (AITIG) within the framework of ASEAN - India Free Trade Area. These are very favourable conditions to promote bilateral trade relations between the two countries Vietnam and India. Under Modi, India is implementing the Act East policy, which affirmed that Vietnam is an important pillar. This is the basis for the two countries to take advantage of the potential and advantages to further cooperation in the exploration and development of investment cooperation and trade relations. By the end of 10/2014, Prime Minister of India, Modi declared to willingly lend Vietnam $\$ 300$ million credit to help Vietnam "diversify the links between the industry and the economy". On January 20, 2015, the second session of the mixed Commerce Subcommittee Vietnam - India took place in Hanoi, the two sides agreed to continue encouraging and creating favourable conditions for enterprises of the two countries to cooperate in business, striving to level two-way trade turnover between Vietnam - India to $\$ 15$ billion by 2020. In the oil and gas sector, ONGC Videsh Limited (OVL) and Essar Oil are already providing oil and gas exploration services in Vietnam along with PetroVietnam. The cooperation between the two countries in other economic sectors also gained many important achievements. In the context of rising tensions in the South China Sea, India has still expressed persistent cooperation with Vietnam, not a humble attitude to the provocation and threats from China. Moreover, India Vietnam cooperation in the oil and gas issues sector is also becoming more and more tightening.

In the areas of cooperation, India - Vietnam security and defence cooperation is an important part. India has always shown their commitment to modernizing national defence and security forces for Vietnam through the expansion of training programs, joint military exercises, share experiences, and providing defense equipment (Press Information Bureau, Government of India, Prime Minister's Office, 2014). Besides, Vietnam has also supported the Indian Navy to strengthen its presence in the South China Sea through the presence of Indian warships in Vietnam. This is considered as an important commitment, which is the basis for accelerating the process of defense cooperation between India and Vietnam in the new international context. In May 2015, the Minister of Defense of the two countries signed the "Vietnam - India Declaration of a common vision on defense ties during 2015-2020". The above-mentioned Declaration is issued on the framework for the bilateral defense and security relationship in order to enhance the cooperation. The two countries signed agreements in a wide range of 3 military branches covering Navy, The Army, and the Air Force as well as several areas such as defence industry and training, UN peacekeeping operation, and a technical agreement on sharing non-military maritime. In June 2016, Indian Defense Minister Manohar Parrika officially visited Vietnam. During this visit, the defense leaders of the two countries finalized further measures to promote the cooperation in accordance with the content of "Vietnam - India Declaration of a common vision on defense ties during 2015-2020"; considering defense cooperation as an important pillar of the strategic partnership, which focuses staff training, navy, air defense-air force, communications, defense industry, and peacekeeping... In the field of security cooperation, the two countries has strengthened coordination in crime and terrorism prevention criminal justice, criminal science, and international drug control. At the same time, the two countries also work closely and support each other at multilateral forums such as the United Nations, Association of Southeast Asian Nations (ASEAN), Regional Security Forum (ARF), and ASEAN Defense Minister's Expansion (ADMM +) ... In its role as the India - ASEAN coordinator in the 2015 - 2018 period, Vietnam had supported India to implement "East Action” policy, regional connectivity initiatives...

In fact, India and Vietnam can do more to strengthen diplomatic and military coordination more effectively when the two countries have more points in common in their strategic calculations. In the new international context, the competition for impact between India and China is going on fiercely in Southeast Asia. Therefore, the basis of ties between India and Vietnam is now also coming from China. Concerns about China's aggressive, provocative actions in the South and East China Seas such as its maritime territorial expansion and defiance of international standards are the main reasons for upgrading the India-Vietnam relationship to the level of comprehensive strategic partnership. With the legitimate and direct interests from the South China Sea and the Indian Ocean, India and Vietnam have had a profound sharing of the dangers coming from China's ambitions. The disagreements and threats coming from this country [with China] have created similar levels of interest in the foreign policy of the two countries towards China. The increasingly complex tensions between Vietnam and China, especially the interests and position of Vietnam in the Indochina, have helped Vietnam become a natural partner with India to balance the power with China (Rajendram, 2014). To prepare for the relief of the growing pressure from China in the Indian Ocean region, India has chosen to strengthen ties with Vietnam to approach to the Asia - Pacific. In return, Vietnam is also aware of the need to strengthen relations with key partners like India to promote multilateral balance in relations with major countries, with China at hand (Thayer, 2014).

Under Prime Minister Modi's administration, India is gradually expanding relations with Vietnam as China is doing with Pakistan in South Asia, basis for the New Delhi to wield strategic influence in the South China Sea and Southeast Asia (Pant, 2018a). Strategically, if China wants to expand its presence in South Asia and the Indian Ocean region through the Pakistan factor, India can do the same in Southeast Asia and the South China Sea through the development of strategic 
relations with Vietnam. If China can have a strategic partnership with Pakistan ignoring Indian concerns, India can develop robust ties with states on China's periphery such as Vietnam without giving China a veto on such relationships (Pant, 2018b). In these contexts, India has been willing to compete for influence with China in its backyard, thus contributing to the balance of power in the region. In fact, India's stance is being welcomed by countries such as Vietnam, which are very concerned by China's increasingly aggressive attitude toward expansion in the South China Sea in particular and Southeast Asia in general. The Vietnam-India comprehensive strategic partnership should be considered in the context of India's approaches with many changes from The Obama administration's rebalance strategy to The Trump administration's India-Pacific strategy.

Moreover, several changes in US-Vietnam relations motivate India to promote cooperation with Vietnam. According to Harsh V. Pant, "India's outreach to Hanoi comes at a time when the United States has lifted its long-standing ban on the sale of lethal military equipment to Vietnam. New Delhi's abiding interest in Vietnam too is in the defence sector. It wants to build relations with countries such as Vietnam, so they can act as pressure points against China" (Pant, 2018b). In fact, all India, the US, and Vietnam want to prevent China from dominating the maritime trade routes. In the context that China deploys surface-to-air missiles on artificial islands in the South China Sea, Vietnam sees the US presence as a "deterrent" to China's growing military. However, strong diplomatic and security supports for Vietnam from regional powers such as India, Japan, and Australia will be credible deterrent aids. In addition, New Delhi's economic commitments to Vietnam and the region are also another factor that causes countries concerned, especially ASEAN, to see India as a possible force and maintain the balance of power in the region.

\section{CONCLUSION}

In the past 20 years, the world seemed to be saluted by the rapid emergence of China but paid very little attention to the growing resurgence of India. With the spread of Indian businesses in the world today under the condition of a downside global economy, India can leverage their strengths to adapt and overcome the economic growth of China. In the intertwined context of cooperation and competition, the "rise" of India has been having a lot of effects on Asia in particular and on the world in general. In a certain sense, the rise of India can be seen as a "phenomenon" of Asia. Synchronized with the dynamic development of the Asia-Pacific region, the "rise" of India has made Asia more noticeable in the perspective of the major powers in the region and beyond. The rapid rise of a powerful entity in South Asia has brought not only tempting implications but also potential risks to the Asian country. The "rise" of India contributes to the common development of Asian countries and affirms the position of Asia on the world map.

In the context of India's strong "rise" recently, Vietnam has always played an important role, as the focus of the "Look East Policy" of India. India - Vietnam relations with sustainable progress over the time of history has proved the fact that these two countries have many similarities in the national interest and share a common view on various issues of bilateral and multilateral at both regional and international levels. It can be noticed that "the benefits of economic convergence and security" is the basis for convincing the two partners to promote close relations. The ties between India and Vietnam have helped India become a peaceful superpower dominating East Asia, especially the Southeast Asia. Strengthening Indian Vietnam relations has also paved the way for India to play a larger role in shaping the regional security structure in Asia Pacific. The development of a sustainable Vietnam-India partnership will make an important contribution to realizing India's strategic interests in the South China Sea in the maritime sectors, aiding Vietnam's efforts to strengthen the presence of trusted international partners in the region. In the context that the "Look East Policy" has been gaining positive results and moving into a new period with the "Act East", Vietnam is playing a much more important role in the strategic priorities of India in Southeast Asia. When selecting Vietnam, India has proven itself as a key factor in the Asia Pacific.

\section{LIMITATION AND STUDY FORWARD}

As a research study and analysis of the rise of India in the new balance of power in Asia since the beginning of the $21^{\text {st }}$ century and its impact on India-Vietnam relations, this study contributed some findings. However, these limitations are related to lacking a suitable theory or framework for research about international relations in Asia. Its intention also addresses larger questions for researchers and scholars about the idea of international relations theories for Asia within its wider analytical and theoretical context.

\section{IMPLICATIONS OF THE STUDY}

With the main findings, the study provides a detailed look at the rise of India in a new era, which will support scientific researchers, scholars, observers, and students to have more perspectives approaching the topic. Moreover, this study could be valuable documents in the field of scientific research of international relations, history, and politics.

\section{ACKNOWLEDGMENT}

The author confirms that the data do not contain any conflict of interest. Thank you, editors, and my friends, and Mr. Dinh Tran Ngoc Huy to support this publication. 


\section{REFERENCES}

1. Babbage, R. \& Gordon, S. (1992). India's Strategic Future: Regional State or Global Power?Macmillan.https://doi.org/10.1007/978-1-349-21885-1

2. Banskota, N. P. (2012). South Asia Trade and Energy Security: The Role of India, Boca Raton. Universal Publishers, 59-74.

3. Bertsch, G., Gahlaut, S., Srivastava, A. (1999). Engaging India: U.S. Strategic Relations with the World's Largest Democracy.Routledge, 38-39. https://doi.org/10.4324/9780203825433

4. Bhatia, R. (2013). Learning to live in a new Asia.The Hindu. Retrieved from http://www.thehindu.com/opinion/op-ed/learning-to-live-in-a-new-asia/article4895513.ece

5. Bhatia, R. (2014). Namo takes on dragon; Modi's leanings towards Vietnam, a challenge to China. Retrieved fromhttp://www.deccanchronicle.com/141102/commentary-op-ed/article/namo-takes-dragon-modis-leaningstowards-vietnam-challenge-china

6. Brewster, D. (2012). India as an Asia Pacific Power. Routledge.https://doi.org/10.4324/9780203637685

7. Dang Cong san Viet Nam [Vietnam Communist Party] (2011).Van kien Dai hoi dai bieu toan quoc lan thu XI (Vietnamese) [Eleventh National Congress Official Documents]. National Political Publishing House, 237.

8. Dat, P.M., Mau, N.D., Loan, B.T.T., \& Huy, D.T.N. (2020). Comparative China Corporate Governance Standards after Financial Crisis, Corporate Scandals and Manipulation, Journal of Security and Sustainability Issues, 9(3): 931-941.https://doi.org/10.9770/jssi.2020.9.3(18)

9. Deo, N. (2015). India's tilt to the East. Indian Council on Global Relations, Retrieved fromhttp://www.gatewayhouse.in/indias-tilt-to-the-east/

10. Do, D. T. (2012). Quan he Viet Nam - An Do, tu huu nghi gan bo huong toi hop tac toan dien doi tac chien luoc (Vietnamese) [Vietnam-India relationship, from close friendship towards the comprehensive strategic partnership], in Ngo, X. B.et al. (2012).Viet Nam, An Do va Tay Nam A - Nhung moi lien he trong lich su va hien tai (Vietnamese) [Vietnam, India and Southwest Asia countries - Historical and Present Relationships].Literally Encyclopaedic Dictionary of Vietnam, 73.

11. Dupont, A. (2012). An Asian Security Standoff.The National Interest, 119, 55-61.

12. Elliott, D. W. P. (2012). Changing Worlds: Vietnam's Transition from Cold War to Globalization. Oxford University Press, 260.https://doi.org/10.1093/acprof:oso/9780195383348.001.0001

13. Gupta, R. (2007). India's "Look East" policy".In Sinha, A.\& Mohta, M. (2007).Indian Foreign Policy: Challenges and Opportunities. Foreign Service Institute/Academic Foundation, 377.

14. Haass, R. (2008). The Age of Nonpolarity: What Will Follow U.S. Dominance?.Foreign Affairs. 87(3), 44-56.

15. Hagerty, D. T.et al. (2005). South Asia in World Politics. Lanham, Md.: Rowman \& Littlefield Publishers.

16. Hart, A. F. \& Jones, B. D. (2010). How Do Rising Powers Rise? Survival: Global Politics and Strategy, 52(6), 63-88. https://doi.org/10.1080/00396338.2010.540783

17. Huy, D.T.N. (2015). The Critical Analysis Of Limited South Asian Corporate Governance Standards After Financial Crisis. International Journal for Quality Research, 9(4).

18. Ikenberry, G. J. (2008). The Rise of China and the Future of the West: Can the Liberal System Survive?. Foreign Affairs, 87(1), 23-37.

19. Kapur, A. (1997). Nuclear policies of small states and weaker power: the national security of small states in a changing world. Frank Cass, 113.

20. Kesavapany, K., Mani, A., Ramasamy, P. (2008). Rising India and Indian Communities in East Asia. Institute of Southeast Asian Studies, 126-127.https://doi.org/10.1355/9789812308009

21. Ladwig, W.C. (2010). India and Military Power Projection: Will the Land of Gandhi. Become a Conventional Great Power? Asian Survey, 50(6), 1162-64.https://doi.org/10.1525/as.2010.50.6.1162

22. MacKie, D. (2016). The Race to Superpower Status.Asian Affairs. Retrieved from http://www.asianaffairs.in/ 2016/03/the-race-to-superpower-status/

23. Mahbubani, K. (2008). The new Asian hemisphere: the irresistible shift of global power to the east. Public Affairs.

24. Majumdar, S. K. (2012).India's Late, Late Industrial Revolution: Democratizing Entrepreneurship. Cambridge University Press, 297.https://doi.org/10.1017/CBO9781139057455

25. Malik, M. (2014). China and Strategic Imbalance.The Diplomat. Retrieved from http://thediplomat.com/2014 /07/china-and-strategic-imbalance/

26. Meredith, R. (2008).The Elephant and the Dragon: The Rise of India and China and What It Means for All of Us. W. W. Norton, 57.

27. Mishra, R. (2014). India-Vietnam: New Waves of Strategic Engagement.India Council of World Affairs, 1-8. https://www.icwa.in/showfile.php?lang=1\&level=2\&ls_id=1409\&lid=155\&arch=1\&sh_arch=1

28. Mochizuki, M. M.\& Porter, S. P. (2013). Japan under Abe: Toward Moderation or Nationalism?The Washington Quarterly, 36(4), 25-41. https://doi.org/10.1080/0163660X.2013.861709

29. Nguyen, D. L. A. (2012a). Quan niem ve chu quyen cua Trung Quoc (Vietnamese) [The concept of Chinese sovereignty], Journal of Chinese Studies, 3 (127), 71.

30. Nguyen, H. G.et al. (2012b).Mot so van de chinh tri quoc te trong giai doan hien nay(Vietnamese) [Some 
international political issues in the current period]. National Political Publishing House of Vietnam.

31. Nguyen, V. D. (2014). Dia chinh tri trong chien luoc va chinh sach phat trien quoc gia (Vietnamese) [Geopolitics in national development strategy and policy]. National Political Publishing House of Vietnam, 262.

32. Pant, H. V. (2018a).India and Vietnam: A "Strategic partnership" in the making. Policy Brief. S. Rajaratnam School of International Studies, 7. https://www.rsis.edu.sg/wp-content/uploads/2018/04/PB180409_-India-andVietnam.pdf

33. Pant, H. V. (2018b). Why Vietnam is at the center of India's policy to counter China?Retrieved from https://www.orfonline.org/research/why-vietnam-centre-india-policy-counter-china/

34. Patnaik, S. K. et al.(2004). United Nations, India and The New World Order. MittalPublication, 134.

35. Pham, Q. T. (2011). Con rong kinh te Trung Quoc va he luy doi voi the gioi(Vietnamese) [The Chinese economic dragon and its implications for the world].Journal of International Studies, 1 (84), 119.

36. Pham, T. Q.et al. (2013). Trung Quoc va An Do troi day: Tac dong va doi sach cua cac nuoc Dong A (Vietnamese) [The Rise of China and India: Impacts and Policies of East Asian Countries]. Social Sciences Publishing House, 80.

37. Prakash, A. (2011). The Rationale and Implications of India's Growing Maritime Power. In Kugelman, Met al. (2011). India's Contemporary Security Challenges.Woodrow Wilson International Center for Scholars, 80.

38. Press Information Bureau, Government of India, Prime Minister's Office (2015). English Rendering of the Prime Minister's Media Statement during the visit of Prime Minister of Vietnam to India.Retrieved from http://pib.nic.in/newsite/PrintRelease.aspx?relid=110863

39. Ragavan, T. V(2015). Make in India and Its Strength to Become India a Manufacturing Hub. International Journal of Engineering, Business and Enterprise Applications, 13(1), 37-39.

40. Rajendram, D. (2014). India's new Asia-Pacific strategy: Modi acts East. Lowy Institute for International Policy. Retrieved from http://www.lowyinstitute.org/files/indias-new-asia-pacific-strategy-modi-acts-east.pdf

41. Sachdeva, G. (2016). India in a Reconnecting Eurasia: Foreign Economic and Security Interests. Rowman and Littlefield, 4.https://doi.org/10.1080/01402390.2012.728134

42. Scott, D. (2013). India's Aspirations and Strategy for the Indian Ocean: Securing the Waves? Strategic Studies, 36(4), 486. https://doi.org/10.1007/978-81-322-2541-6 14

43. Singh, N. (2016). Information Technology and Its Role in India's Economic Development: A Review.In Dev, S. M. \& Babu, P. G.(2016).Development in India: micro and macro perspectives. Springer, 283-312.

44. Suganuma, U. (2000). Sovereignty Rights and Territorial Space in Sino-oapanese Relations: Irredentism and the Diaoyu/Senkaku Islands. University of Hawaii Press, 152.https://doi.org/10.4324/9781315768915

45. Tabata, S.et al. (2015).Eurasia's Regional Powers Compared: China, India, Russia. Routledge, 142-144.

46. Tang, Lames T.H (2011). Northeast Asia Without the United States: Towards Pax Sinica. In Flake, L.G.et al. (2011). One Step Back? Reassesing an Ideal Security State for Northeast Asia 2025. Mansfield Foundation, 105116.

47. Thayer, C. A. (2014). India-Vietnam: Consolidating Bilateral Ties.Diplomatist, 2(1), 51-52.

48. Tran, V. T. (2013). Su khac biet giua mo hinh phat trien kinh te cua Trung Quoc va An Do(Vietnamese) [Differences in Economic Model between China and India], in Ngo, X. B.et al. (2012)Viet Nam, An Do va Tay Nam A - Nhung moi lien he trong lich su va hien tai (Vietnamese) [Vietnam, India and Southwest Asia countries - Historical and Present Relationships].Literally Encyclopaedic Dictionary of Vietnam, 426.

49. Zakaria, F. (2006). India Rising.Newsweek. Retrieved from http://www.newsweek.com/india-rising-106259 